\title{
Assessing Farmers' Decision-Making in the Implementation of Jajar Legowo Planting System in Rice Farming Using a Logit Model Approach in Bantul Regency, Indonesia
}

\author{
Eni Istiyanti ${ }^{1, *}$ \\ ${ }^{1}$ Universitas Muhammadiyah Yogyakarta, Agribusiness Department, 55183 Yogyakarta, Indonesia
}

\begin{abstract}
Jajar Legowo is one of the planting systems in rice farming. Proper implementation of this system can increase farmers' production and income. This research aims to describe the characteristics of farmers based on internal and external factors and analyze the factors influencing of decision making in the implementation of the Jajar Legowo planting system. Respondents were taken using a stratified random sampling method, as many as 50 farmers consisting of 25 farmers who implemented the Jajar Legowo planting system and 25 farmers who used a conventional system. The characteristics of rice farmers were explained descriptively in a tabular form. The binary logit regression model was used to analyze the factors influencing farmers' decision making. The results show most of the rice farmers implementing both the Jajar Legowo and the conventional systems were of productive age with elementary school education. The land area and income of Jajar Legowo farmers were higher than conventional farmers. The social and economic environments of both the planting system were already high. Nature of Innovation of the farmers applying Jajar Legowo planting system were high. The variables income, land area, and the nature of innovation influenced farmers' decision making in implementing Jajar Legowo planting system.
\end{abstract}

\section{Introduction}

Rice is a staple food source in Indonesia. As a primary food crop, rice has the economic potential to create national food security [1]. Estimated rice production and productivity increase from year to year and the government continues to increase national rice production by up to $5 \%$ per year [2]. Based on the National Socioeconomic Survey (Susenas), average rice consumption was $1.98 \mathrm{~kg} / \mathrm{capita} / \mathrm{week}$, equivalent to 103.18 $\mathrm{kg} /$ capita/year [3]. Food demands increase in line with population growth. To protect national food security, Indonesian rice production must increase in quantity and efficiency.

\footnotetext{
*Corresponding author: eniistiyanti@umy.ac.id
} 
Efforts to increase rice production can be actualized through crop intensification. Regulating planting systems and incorporating seedlings that are well-developed and from superior varieties promotes plant growth and leads to optimal production. Rice is usually grown in rice fields where varieties with narrow planting space conditions will experience a decrease in growth quality defined by fewer tillers and panicles, shorter panicle lengths, and a reduction in the number of grains per panicle compared to rice grown with wide plant spacing [4].

There are several types of rice planting systems, including: direct seed planting (Tabela), no-tillage planting (TOT), System of Rice Intensification (SRI), and Jajar Legowo (Jarwo). The Jajar Legowo planting system is a technique where rice is planted with a repeating pattern that incorporates several rows of plants interspersed with one empty row. Initially, it was applied to areas having a lot of pests and diseases. However, this planting system has been developed to provide higher yields by increasing plant population and optimizing growing space [4].

As shown by [5] production and income from rice farming using the Jajar Legowo planting system are higher than "Tegel" planting schemes. The productivity of rice farming with Jajar Legowo is $12 \%$ higher compared to "Tegel" systems. The rice production using the 2:1 Jajar Legowo method is higher than the 4:1 method and "Tegel" planting system [6] and that rice farming income using the Jajar Legowo is higher than the SRI [7]. Nevertheless, not all rice farmers implement it.

Most research of the Jajar Legowo planting system has examined its potential for income, productivity, and profit, while research into the decision-making by farmers using the logit approach has never been undertaken. The willingness of farmers to implement the Jajar Legowo planting system is mostly influenced by social, economic, environmental, and internal factors. To encourage optimal production levels, the government needs to encourage innovation that is adapted to farmers' specific concerns. Using a binary logit model approach, this study aims to describe the decision-making of rice farmers deciding whether to implement the Jajar Legowo planting system and the factors that influence them.

\section{Research Method}

This research was conducted in Bantul Regency, Special Region of Yogyakarta, Indonesia. The location was chosen based on the significant number of rice farmers implementing the Jajar Legowo planting system within incorporated farmer groups. By using a stratified random sampling, 50 rice farmers were selected as respondents. These respondents were taken from Sedyo, Mukti, and Subur farmer groups and consisted of rice farmers either implementing a conventional system or employing the Jajar Legowo system.

Factors influencing farmers' decision to implement Jajar Legowo consist of internal and external factors. Internal factors include: farmer age and education, farm income, and land area; external factors include: social environment, economic environment, and the nature of innovation [8]. Social environment indicators were the support from neighbors, farmer groups, and the government, and assistance in the production facilities, marketing and credit. The economic environment variable also consists of 2 indicators, namely the availability of production facilities include ease of getting, complete and always available if needed and credit availability indicators include always available, the government provides and facilitating farmer groups. Assessment of each indicator from the social and economic environments consisted of three questions, so the number of questions items on social and economic environment variables is 6 . The scored for each question is from 1 (strongly disagree) to 4 (strongly agree). The results represent the sum of the scores of all 
questions (minimum total score 6 and maximum 24) and made into four categories, namely 1 (very low), 2 (low), 3 (high), and 4 (very high).

The indicators of the nature of innovation were relative advantages, compatibility, complexity, trialability (ease of implementing) to, and observability, each of which consisted of four questions, so the number of questions items on nature of innovation variable is 20. Each question is given a score ranging from 1 (strongly disagree) to 4 (strongly agree). The total score of all questions (minimum total score 20 and maximum 80) was made into four categories of innovation, namely 1 (very low), 2 (low), 3 (high), and 4 (very high).

A binary logit regression model [9] and [10] can be used to analyze the influence of independent variables such as farmers' age and education, land area, farm income, social environment, economic environment, and the nature of innovation on farmers' decision to implement the Jajar Legowo planting system. Before carrying out an analysis, a validity test should first be done using a product-moment correlation test. In this case, each question score on the independent variable of external factors as well as social environment, economic environment, and the nature of innovation was tested for correlation with the total score of the independent variable. The correlation between the scores of each question item and a total score should be $>0.25$, and if it is $<0.25$, then the item must be removed. In addition to a validity test, a reliability test should also be carried out using Cronbach's alpha. If the alpha value is low $(<0.2)$ based on the Guilford criteria, there may be one or several items creating unreliable variables that must be removed to increase the alpha value.

After testing validity and reliability, the variables meeting the requirements were analyzed using the binary logit regression model, mathematically written as follows:

$$
\underset{(1-p)}{\operatorname{Ln} p}=\beta 0+\beta 1 X 1+\beta 2 X 2+\beta 3 X 3+\beta 4 X 4+\beta 5 X 5+\beta 6 X 6+\beta 7 X 7
$$

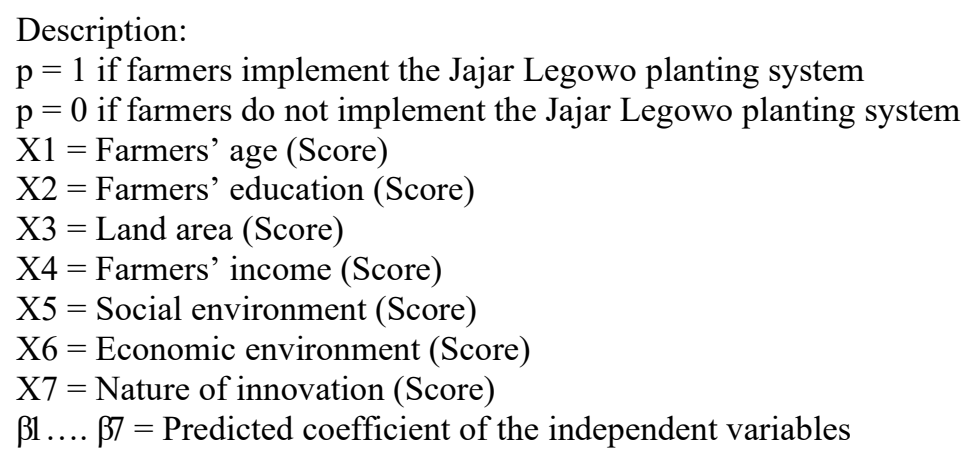

Parameter Testing

Simultaneous Test (G-test): This is a test of the influence of independent variables (age, education, land area, income, social environment, economic environment, and nature of innovation) on the dependent variable (farmers' decision to apply the Jajar Legowo planting system). The hypothesis used in the G-test is as follows:

$\mathrm{H} 0: \beta 1=\beta 2=\ldots .=\beta 7=0$

$\mathrm{Ha}$ : there is at least one $\beta \neq 0$

$\mathrm{G}>\mathrm{X}^{2}$ means that, in aggregate, the variables of age, education, land area, income, social environment, economic environment, and the nature of innovation influence the farmers' decision to apply the Jajar Legowo planting system. 
Model Suitability Test: This test was carried out using SPSS software and Hosmer and Lemeshow's output measured by Chi-square value or p-value [10]. If the p-value < Chi-square table, then the model used is appropriate and can explain the data.

Wald Test: This test was used to test the effect of each independent variable on the farmers' decision to apply the Jajar Legowo planting system. It was carried out by comparing the amount of Wald obtained from logistic regression with the Chi-square table. $\mathrm{Wj}>\mathrm{X} 2$ means that independent variable $\mathrm{j}$ partially influences farmers' decision to apply the Jajar Legowo system.

\section{Results and Discussion}

\subsection{The Characteristics of Rice Farmers Based on Internal and External Factors}

Farmers' decision in applying the Jajar Legowo planting system are influenced by internal and external factors. Internal factors consist of age, education level, land area, and farm income, while external factors comprise the social environment, economic environment, and the nature of innovation.

Table 1. Characteristics of Farmers Based on Internal Factors

\begin{tabular}{|l|l|l|l|l|}
\hline \multirow{2}{*}{ Description } & \multicolumn{2}{|c|}{ Jajar Legowo } & \multicolumn{2}{c|}{ Conventional } \\
\cline { 2 - 5 } & Total (person) & Percentage (\%) & $\begin{array}{l}\text { Total } \\
\text { (person) }\end{array}$ & $\begin{array}{l}\text { Percentage } \\
\text { (\%) }\end{array}$ \\
\hline Age (years): & & & & \\
\hline $38-49$ & 5 & 20 & 4 & 16 \\
\hline $50-61$ & 9 & 36 & 10 & 40 \\
\hline $62-73$ & 6 & 24 & 10 & 40 \\
\hline $74-85$ & 5 & 20 & 1 & 4 \\
\hline Education: & & & & \\
\hline No School & 3 & 12 & 4 & 16 \\
\hline Elementary & 12 & 48 & 8 & 32 \\
\hline Yunior High & 3 & 12 & 8 & 32 \\
\hline Senior High & 7 & 28 & 5 & 20 \\
\hline Land Area (m 2 ) & & & & \\
\hline$<1.000$ & 10 & 40 & 22 & 88 \\
\hline $1,000-1,999$ & 13 & 52 & 1 & 4 \\
\hline $2,000-2,999$ & 0 & 0 & 2 & 8 \\
\hline$\geq 3.000$ & 2 & 8 & 0 & 0 \\
\hline Income (IDR): & & & & \\
\hline $320,000-843,749$ & 5 & 20 & 6 & 24 \\
\hline $843,750-1,367,499$ & 13 & 52 & 16 & 64 \\
\hline $1,367,500-1,891,249$ & 4 & 16 & 1 & 4 \\
\hline $1,891,250-2,415,000$ & 3 & 12 & 2 & 8 \\
\hline
\end{tabular}

Table 1 shows that more than $50 \%$ of farmers applying both systems were of productive age. Productive age is a group in characterized by the ability to carry out an activity. A person in the productive age range is in prime physical condition and capable of responding to changes and innovations. Surprisingly, the results show that the number Jajar Legowo farmers above the productive age was greater than those employing conventional systems. This result contrasts with the findings of [11] in which the number of productive age organic rice farmers in Belgrade, Serbia, was higher than the number of conventional farmers. 
In terms of education, the majority of farmer respondents in this study had an elementary school education. The Jajar Legowo rice farmers in Subak Giri, Bali, also had low education, and most farmers can apply the Jajar Legowo planting system because the level of formal education completed is not a decisive indicator of successful farm management [7].

More than $90 \%$ of farmer respondents owned land areas of less than $2,000 \mathrm{~m}^{2}$, although the farms applying the Jajar Legowo system were wider than those of using a conventional system. However, these results differ from the Jajar Legowo farming system in West Sumatra where $90 \%$ of farmers each possessed more than 2,500 $\mathrm{m} 2$ of land [12]. Because the Jajar Legowo system requires leaving empty rows to optimizing sunlight for plants, having more farmland makes it easier for farmers to apply the system [4].

Table 2. Characteristics of Farmers Based on External Factors

\begin{tabular}{|l|l|l|l|l|}
\hline \multirow{2}{*}{ Description } & \multicolumn{2}{|c|}{ Jajar Legowo } & \multicolumn{2}{c|}{ Conventional } \\
\cline { 2 - 5 } & Score & Category & Score & Category \\
\hline Social Environment & 16.32 & High & 16.88 & High \\
Economic Environment & 22.64 & Very High & 15.24 & High \\
Nature of Innovation & 57.36 & High & 46.68 & Low \\
\hline
\end{tabular}

Notes: Social and economic environment score: 6-24

Nature of innovation score: $20-80$

Table 2 shows that the social environment of both Jajar Legowo and conventional farmers was already high. Support from neighbors, farmer groups, and the government, as well as assistance in the form of production facilities, marketing, and credit, are factored in by both conventional farmers and those applying the Jajar Legowo system. The most influential support for either farming system comes from neighbors, while the lowest is from the government. The most assistance farmers receive is in the production facilities in the form of seeds and fertilizer from the government; at the same time, marketing assistance was rarely obtained from either farmer groups and the government.

The influence of economic environment category was rated quite highly by Jajar Legowo farmers who found production facilities always available and easily accessible. Likewise, the availability of credit was a significant factor for Jajar Legowo farmers; the government generously provided credit, and farmer groups facilitated it. Similary generosity was unavailable for conventional farmers, so this economic environment strongly supported farmers applying the Jajar Legowo system.

Based on the relative advantage of the nature of innovation, Jajar Legowo rice farmers reaped greater profits than conventional farmers. Especially in terms of compatibility, rice farming with the Jajar Legowo system was more appropriate than the conventional system as it was able to reduce costs and increase production. The Jajar Legowo system had a low score on the indicator of trialability (easy of implementing) caused by the difficulty in getting help from workers outside the family for planting. Planting activities in the Jajar Legowo system were usually carried out by planting teams consisting of 8 to10 people.

The complexity was similar for both the Jajar Legowo and conventional system farms. The stages in rice farming in the Jajar Legowo system involving nursery, land preparation, planting, clearing of weeds, and harvesting, are not different from those in Bangladesh [13]. The wider spacing in the Jajar Legowo system facilitates fertilization, pest and disease control, and weed reduction, resulting in more optimal plant growth [4] and higher productivity[5] 


\subsection{Factors Influencing Farmers' Decision to Implement the Jajar Legowo Planting System}

The estimation of the model of factors influencing farmers' decision in applying the Jajar Legowo system was performed using a binary logistic regression analysis with SPSS software. Before analysis, it was necessary to test the validity and reliability of all questions forming the variables of the social environment (6 questions), economic environment (6 questions), and the nature of innovation (20 questions). Based on an analysis of the product-moment correlation between all questions forming the variable of social environment, items with a total score of $>0.25$ were said to be valid. Similar efforts were also applied to the economic environment and the nature of innovation variables. Based on reliability testing, Cronbach's alpha values returned at 0.907 , placing it in the very high category according to the Guilford criteria therefore, the variables are reliable.

Before application, the feasibility of the model was tested and the result indicated that without including the independent variables, the model did not fit the data. However, after adding the independent variables of age, education, land area, income, social environment, economic environment, and the nature of innovation, the model could predict the data, meaning that it was appropriate to use it with values of -2 likelihoods (39.59) < Chi-square (54.09).

The results of simultaneous testing with the G-test indicate that the independent variables comprising age, education level, land area, farm income, social environment, economic environment, and the nature of innovation, had a significant effect on the dependent variable of the farmers' decision to apply the Jajar Legowo system. The results are consistent with the study of [14], which discovered that age and education level of the head of the family, farm income, family labour, socio-economic factors, and land management all influenced the continuity of farming in Jordan. Meanwhile, the socioeconomic factors influencing women in Nigeria in making decisions in agriculture were the level of formal education, farming experience, finance, working hours in agriculture, and the scale of business[15]

Table 3. Factors Affecting Farmers' Decision to Implement the Jajar Legowo System (Wald Test)

\begin{tabular}{|l|r|r|r|r|}
\hline Variable & \multicolumn{1}{|c|}{ B } & \multicolumn{1}{c|}{ Wald } & \multicolumn{1}{c|}{ Sig. } & \multicolumn{1}{c|}{$\operatorname{Exp(B)}$} \\
\hline Age & 0.090 & 0.021 & 0.885 & 1.094 \\
\hline Education & -0.073 & 0.014 & 0.906 & 0.930 \\
\hline Land Area & $2.953 * *$ & 4.729 & 0.030 & 19.166 \\
\hline Farming Income & $-1.896 *$ & 3.857 & 0.050 & 0.150 \\
\hline Social Environment & 0.120 & 0.342 & 0.559 & 1.127 \\
\hline Economic Environment & 0.259 & 0.702 & 0.402 & 1.295 \\
\hline Nature of Innovation & $0.206 * *$ & 5.016 & 0.025 & 1.228 \\
\hline
\end{tabular}

Notes: $\quad * *$ Siginificant at $\alpha 5 \%$

* Significant at $\alpha 10 \%$

Table 3 shows that variables of land area and the nature of innovation had a positive effect on farmers who decided to apply the Jajar Legowo system, while farm income had a negative effect. Furthermore, farmers' age and level of education, social environment, and economic environment did not significantly influence their decision making.

The age of farmers had a regression coefficient of 0.090 , meaning that it did not have a significant effect on farmers' decision to apply the Jajar Legowo system; this can be seen from the Wald value of 0.021 with a significance of $0.885>0.1$. Similarly, that age 
had no significant effect on farmers' decision making [16] and [14]. Conversely, age was found to have a negative effect on farmers' decision to exit farming in agricultural Switzerland [17]. The odds ratio for the age of farmers in this study was 1.094, meaning that older farmers were more likely to apply the Jajar Legowo system than younger farmers. While $20 \%$ of Jajar Legowo farmers were "very old" ( $>73$ years), only $4 \%$ of conventional farmers were similarly aged.

The Wald value of 0.014 and the significance of $0.906>0.1$ means that the level of education did not significantly influence farmers' decision. Previous studies, such as [18] reported similar findings regarding the relevance of education level. In contrast, [19] discovered that farmers' education had a negative effect on decision-making in organic farming in Turkey. In the instant study, the odds ratio value was 0.93 , which means farmers with low education were likely to have a higher chance of implementing the Jajar Legowo system than farmers having higher education. Data shows that $60 \%$ of Jajar Legowo farmers had primary school education or no school education compared to $48 \%$ of conventional farmers.

The fact that farmers' education is quite low has pushed the central government and local governments of Indonesia have sought various programs to increase rice production. Through the Field School-Integrated Crop Management (FS-ICM) program where FCA (Field Counselor Agriculture) plays a role in increasing rice production [20]. FCA is needed as counselor and coach whose job is to guide, provide direction and explanation, and provide counseling about farming activities to increase rice production [21]. FCA is expected to be able to help farmers in solving problems faced by farmers in implementing the Jajar Legowo planting system.

The area of land had a positive coefficient of 2.953, a Wald value of 4.729 , and a significance of $0.030<0.05$, which means it has a significant effect on the decision. Therefore, it can be concluded that the availability of more land encourages farmers to implement the Jajar Legowo system in rice farming. This is consistent with previous studies by [22] and [23] which discovered that land area had a positive and significant effect on farmers' decision-making. The odds ratio value of the land area of 19,166 means that farmers with large land had a higher chance of applying the Jajar Legowo system 19,166 times greater than to farmers with narrow land.

The regression coefficient of farm income was $-1,896$, and it had a significant effect on farmers' decision with the Wald value of 3.857. A significance of $0.050<0.1$ means that farm income had a negative effect on farmers' decision to apply the Jajar Legowo system. The farmers' income had a negative effect on decision-making in organic livestock in Turkey [20] but found that income had a positive effect on the decision to continue farming on marginal land in Jordan [14]. The value of the odds ratio in this study was 0.150 , which can be interpreted as the opportunity for farmers with high incomes to apply the Jajar Legowo system was 0.15 times smaller than farmers with low incomes.

Having a Wald value of 0.342 and a significance level of $0.559>0.1$ means that the social environment had no significant effect on the decision of farmers to apply the Jajar Legowo system. Moreover, the odds ratio value of 1.127 means that farmers with a high social environment tended to have greater opportunities to apply the Jajar Legowo system than farmers with a low social environment. The encouragement and assistance from both farmer groups and the government the indicators of the social environment were not a factor influencing the implementation of the Jajar Legowo system. Contrarily, that farmer groups served not only as a medium for channeling government assistance but also as an agent for implementing new technologies [24].

Obtaining a Wald value of 0.702 with a significance of $0.402>0.1$ showed that the economic environment with a coefficient of 0.259 had no significant effect on farmers' decision. The odds ratio value of 1.295 can be interpreted to mean that farmers with a 
high economic environment had a greater opportunity to apply the Jajar Legowo system than farmers with a low economic environment. Although production facilities and credit were fully available and easily accessible to farmers contemplating a switch to the Jajar Legowo system, these variables were not sufficient to encourage farmers to apply the Jajar Legowo system. Conversely, the research of [25] [26] revealed that the availability of credit could increase capital for farmers and thus facilitate the application of new technologies to increase production and income.

With a Wald value of 5.016 and a significance of $0.025<0.05$, the nature of innovation had a significant positive effect on farmers' decision to apply the Jajar Legowo system. The odds ratio value of 1.228 means that farmers with high nature of innovation values had a 1,228 times higher opportunity to apply the Jajar Legowo system compared to farmers with low nature of innovation values. Likewise, the research of [19] revealed that the higher the perception of farmers' innovation characteristics, the greater their desire to adopt the system. Innovation can be accepted by farmers in terms of sociocultural values, ideas previously introduced, and farmers' needs for innovation [27]

Table 4. Probability of Farmers' Willingness to Continue to Implement the Jajar Legowo System

\begin{tabular}{|c|c|c|c|c|}
\hline \multicolumn{2}{|c|}{ Probability (\%) } & Category & Total of Farmer & Percentage (\%) \\
\hline \multicolumn{2}{|l|}{$39.7-45.4$} & Low & 14 & 56 \\
\hline \multicolumn{2}{|l|}{$45.5-51.2$} & Medium & 9 & 36 \\
\hline \multicolumn{2}{|l|}{$51.3-56.9$} & High & 2 & 8 \\
\hline \multicolumn{2}{|c|}{ Total } & & 25 & 100 \\
\hline Average & $: 45.6$ & & & \\
\hline Minimum & $: 39.7$ & & & \\
\hline Maximum & $: 56.9$ & & & \\
\hline Median & $: 44.7$ & & & \\
\hline
\end{tabular}

Table 4 shows that the lowest probability of farmers' willingness to continue using the Jajar Legowo system in rice farming was $39.7 \%$, whereas the highest was $56.9 \%$, with an average value of $45.6 \%$. Most farmers (56\%) had a low probability of continuing to apply the Jajar Legowo system, and only $8 \%$ had a high probability. In reality, most farmers did not continuously implement this system. The use of the Jajar Legowo system was not based on objective standards, only on the personal experience of farmers. The probability of farmers' continuing to apply the Jajar Legowo system was lower than the willingness to continue rice farming in the suburban area of Sleman Regency, which has an average probability of 0.533 [28]

\section{Conclusions and Recommendations}

Most of the rice farmers implementing both the Jajar Legowo and the conventional systems were of productive age with elementary school education. The land area and income of Jajar Legowo farmers were higher than conventional farmers. The social and economic environments of both groups of farmers were high enough. However, while the Jajar Legowo system provided greater benefits in rice farming and was appropriate for the regional conditions, it was not easy to implement.

Variables including age, education, land area, income, social environment, economic environment, and the nature of innovation aggregated to affect farmers' decision to apply the Jajar Legowo system. The variables having a significant effect independently were 
land area, farm income, and the nature of innovation. Farmers who did decide to apply the Jajar Legowo system had a low probability of continuing.

The nature of innovation influenced farmers' decision to implement the Jajar Legowo system; however, one indicator of the nature of innovation trialability had a low score. The difficulty farmers face to get the labor for planting is a factor that encourages them to continue implementing the Jajar Legowo system. To encourage more farmers to apply the Jajar Legowo system, there is a need for continuous training, assistance on technical implementation, and to obtain more planting teams in a village so farmers can easily access needed labor.

The writer would like to express gratitude to Publication, Research and Community Service Institute (LP3M) Universitas Muhammadiyah Yogyakarta for providing fund for this research.

\section{References}

1. I. Ustriyana, African J. Agric. Res. 10, 174 (2015).

2. J. Mariyono, Bisnis Birokrasi J. 21, (2014).

3. BPS, Kabupaten Pekalongan Dalam Angka 2014 (Badan Pusat Statistik, Pekalongan, 2015).

4. Litbang, Panduan Sistem Jajar Legowo (Litbang, Jakarta, 2013).

5. S. Permata AL, Widjaya S, JIIA 5, 76 (2017).

6. D. Susilastuti, A. Aditiameri, and U. Buchori, AGRITROPICA J. Agric. Sci. 1, 1 (2018).

7. C. T. D. Yasa, SKD; Kardi, Agrimeta 16, 55 (2018).

8. Soekartawi, Prinsip Dasar Komunikasi Pertanian (Universitas Indonesia Press, Jakarta, 2005).

9. S. Menard, Applied Logistic Regression Analysis (SAGE Publication, Inc, Thousand Oak, 2011).

10. W. Hosmer, D and S. Lemeshow, Applied Logistic Regression (John Wiley \& Sons, Inc., New York, 2000).

11. M. Vassalos, C. R. Dillon, and P. Karanikolas, in Role Knowledge, Innov. Hum. Cap. Multifuncional Agric. Rural Dev. (Belgrade, Republic of Serbia, 2009).

12. D. Hafizah, J. Galung Trop. 4, 89 (2015).

13. D. Talukder and L. Chile, Agric. Econ. Rev. 15, 68 (2014).

14. A. Alassaf, M. Majdalwai, and O. Nawash, African J. Agric. Res. 6, 2755 (2011).

15. A. A. Enete and T. A. Amusa, F. Actions Sci. Rep. 4, 1 (2010).

16. T. Rahim, A., Malik, A., Hastuti, D.R.D., Suryadi, Ainternational J. Adv. Res. 6, 1219 (2018).

17. A. Ferjani, A. Zimmermann, and A. Roesch, Agric. Econ. Rev. 16, 59 (2015).

18. E. Ryan, T. M. Prihtanti, and H. J. Nadapdap, Pros. Semin. Nas. Fak. Pertan. UNS 2, E.53 (2018).

19. N. Demir, C. Sancar, O. Demir, V. Aksakal, and A. Aksoy, Turkish J. Agric. Food Sci. Technol. 4, 313 (2016).

20. A. Shegeda, Agric. Resour. Econ. Int. Sci. E-Journal 4, 148 (2018).

21. F.E. Ikiz, E. Asici, IJPE 13, (2017).

22. R. Sianita, Sosiohumaniora 18, 240 (2016).

23. R. Rokhani, M. Rondhi, E. B. Kuntadi, J. M. M. Aji, A. Suwandari, A. Supriono, and T. D. Hapsari, Agrar. J. Agribus. Rural Dev. Res. 6, (2020).

24. S. Nuryanti, D. Dewa, and K. S. Swastika, Forum Penelitiaan Agro Ekon. 19, 115 (2011).

25. O. O. Adebayo and R. G. Adeola, Antropol. 0073, 313 (2017). 
26. J. Nwaru, J. Rural Community Dev. 6, 129 (2011).

27. K. S. Indraningsih, Agro Ekon. 29, 1 (2011).

28. Triyono, in Third Int. Conf. Sustain. Innov. 2019 - Humanit. Educ. Soc. Sci. (IcoSIHESS 2019) (Yogyakarta, 2019), pp. 472-478. 